\title{
An Experimental Study on Experiential English Writing
}

\author{
Hu Qingkun \\ English Department, Anhui Sanlian College, Hefei, China
}

Email address:

353801960@qq.com

\section{To cite this article:}

Hu Qingkun. An Experimental Study on Experiential English Writing. Education Journal. Vol. 4, No. 5, 2015, pp. 315-319.

doi: $10.11648 /$ j.edu.20150405.31

\begin{abstract}
Experiential English writing teaching is a method which is based on the principles of student-orientation and task-base. Through the concrete experience and cooperation, it aims to help students find the principles of English writing and apply them to the practical writing. The keys of experiential English writing lie in the design of experiential situations and reflect the principles of communicative teaching. The paper briefly introduces the theory of Experiential Learning, puts forward a new method of experiential English writing, and expounds its connotation and main stages. The results show that the experiential English writing method can stimulate students' interests in English writing, enhance their communicative ability, choose the suitable words and sentences and expand the writing contents, which is superior to the traditional product writing method. It is considered as a newly effective writing method.
\end{abstract}

Key words: Innovative Writing Method, Experiential English Writing, Main Stages

\section{Introduction}

For a long time, English writing has always been a difficult problem in English learning and a bottleneck which hinders the students to improve their English level, so it also becomes a focus of the research on language teaching. Some scholars (Wang Wenyu, Wang Lifei 2004: 51) have already summarized the present situations of English writing teaching in China, that is , the existing research on English writing has focused on the text level, mainly on the discourse and language characteristics. There is little research on the writing processes. The truth is that English writing teaching is made by the traditional method and the writing level is judged by the final composition. The teachers focus their attention on grammar, the correctness of the sentences and the spellings, ignoring the writing processes. The writing processes, including how students analyze the title, organize the materials and solve their difficulties in writing, are usually neglected. In fact, teachers should pay more attention to the writing processes and instruct students how to write. In recent years, some scholars have begun to explore the problems in the writing processes. For example, Wu Jin and Zhang Zaixin (2000: 213-218) did research on the popular process teaching and verified the feasibility of the pre-writing stage; Wang Chuming (2000: 207-212) conducted an experiment on the long composition; Shao Jirong (2003: 28-34) studied the effects of the task types and conditions on EFL writing; Wu Hongyun (2006: 31-33) carried out an empirical study of the meta cognitive theory; and Du Aihong (2008: 185-186) explored the meta cognitive theory in the application of writing in English teaching. With the rise of experiential learning, some scholars began to show interests in experiential writing, such as Yin Jingshu (2005: 75-79) explored the relationship between College English writing teaching and empathy experience. However, there is no research on how to apply experiential learning to English writing, how to create a new teaching method of English writing, and how to solve the writing problems in actual writing. The thesis introduces the theory of experiential learning, puts forward the theory of experiential English writing and expounds its connotation, main stages and operations, in order to improve the teaching level of English writing.

\section{Theoretical Summary}

Experiential learning is sometimes referred to as experiential study. Since the foundation of KurtHahn Gordonstun School in 1934, experiential learning and teaching has been popular in the British and American schools. Experiential Learning Theory is proposed by Cooper, an American experiential learning expert. In 1984, he launched his first book Experiential Learning: Experience as the Source of Learning and Development) (Kolb 1984). In it, he reviewed the educational theories of Dewey, Lewin and Piaget, absorbed in the latest results in philosophy, psychology and 
physiology, and formed his unique experiential learning theory. After its publication, the book has become a classic of adventure and training, which has far-reaching impacts on school education. The book describes six characteristics of experiential learning. They are as follows:

Experiential learning refers to the learning process instead of learning results, because learning is a process of insight. And the results are only a past record instead of future knowledge. Cooper described learning as a continuous process of experience, revision and acquisition.

The experiential learning is based on experience. Continuous experience is a powerful fact and also the core of experiential learning theory, which means that all learning is to learn again. Students involve themselves in learning situation with some certain experience. The educators not only teach new ideas, but also deal with or modify the original experience of the students. If the education process starts with guiding and detecting the original theories of learners, and then combine the new and more accurate ideas with the original ones, the learning process will be more effective.

Experiential learning is the process of using the dialectical thinking to resolve the conflicts. In order to learn effectively, the learners need four capacities: concrete experience, reflective observation, abstract summary and action application. Cooper thinks that learning itself is full of tension and conflicts. Students should not only experience and observe positively, but also summarize abstractly.

The experiential learning is a complete process to adapt to the world. The experiential learning includes all the integration of the individuals: thinking, feelings, understanding and behaviors. It is the core process of human being's adaptation to social and natural environment.

Experiential learning is a process of continuous interaction between individual and environment. Experience has double meanings. On one hand, it is involved in the subjective internal environment of individual, such as feelings; on the other hand, the objective external environment is also involved. These two kinds of experience are permeated, mixed and coexisted in a very complex way.

Experiential learning is a process of creating knowledge. Learning is the process of the transformation of both social knowledge and personal knowledge. According o Dewey, social knowledge is the objective accumulation of human cultural experience, and the individual knowledge is the accumulation of individual subjective experience. The key of experiential learning is the transformation from social knowledge to personal knowledge. Cooper defined learning as the process of conversing and creating knowledge.

With the extensive promotion of experiential learning in the world and the influence of this book, the Chinese educational circles also began to introduce experiential learning. Experiential learning in schools and the related research have made great process. But at present, experiential learning is still on the stage of the introduction and operation of theories, and there is still a very long way to go in China. Yang Yonglin (2004:21) pointed out that, as a foreign language teacher, he should first solve the problem of the relationship between thinking globally and acting locally, and carry out the effective teaching activities in order to make great breakthroughs in theory research and teaching concepts. The so-called macro-thinking is to focus on international academic research from a global perspective, to improve their theoretical knowledge and the abilities of problem identification. The so-called acting-locally is to localize the advanced foreign theories, study the cognitive characteristics of Chinese students, connect the present problems in English teaching, and develop and use modern educational technology to improve the abilities of creative teaching and problem solution. Under the guidance of the macro-thinking, combining the situation of English writing in China, we carry out the acting-locally, which includes the definition of the connotation of experiential English writing, the division of main stages and the design of the flow chart.

\section{The Theories of Experiential English Writing}

\subsection{The Connotation of Experiential English Writing}

Experiential English writing is designed for some students, who have nothing to write or express themselves. It is a new method of writing. Its connotation is that teachers let students experience directly through the creation of the teaching situations, or in the ways of reading, watching movies and learning on the Internet. Then the source of life is introduced into English writing teaching. Students experience four stages: concrete experience, interactive experience, abstract summary and composition formation by the ways of perception, interaction, understanding and cooperation. It is involved in the record of words and sentences, paragraph writing, text writing and experiential changes. It is a continuous dynamic writing process of talking, writing, composing and improving.

Goethe once said, "Theory is gray and the tree of life is evergreen." Life is the writing source of both the mother tongue and foreign languages. The students should combine life experience, perceptual knowledge and English writing closely. Then writing can burst the creative sparks. Teachers should pay attention to students' life experience and their perception of growth, help them bridge life and writing, and let them enjoy the happiness and success of writing in life experience.

\subsection{Main Stages}

Cooper thinks that the circle of experiential learning is composed of concrete experience, reflective observation, abstract summary and active application. The whole learning system is a spiral of rising process. After the above-mentioned circle, the concrete experience is quite different from the initial one. We apply the theory of learning circle to experiential English writing, do some modifications and divide them into four stages.

\subsubsection{Concrete Experience}

The first stage of specific experience is the beginning of experiential writing. At first, teachers, through the setting of 
situations, help students take part in the activities and obtain direct experience, or allow them to read English articles, to watch English films and some other materials which are close to their life. These interesting and stylish texts and pictures will stimulate students' to experience. They have the motivation to express their emotions and mobilize their enthusiasm for writing in English. At this time, students have already entered into the stage of concrete experience. They precept the direct experience and search the relevant information. Teachers should prepare the writing topics for students. The students are experiential, while recording the sparks of ideas.

\subsubsection{Interactive Experience}

The second stage includes two kinds of situations: the student-student interaction and teacher -student interaction. The student-student interaction refers to a group of students who use English to communicate with each other on their specific experience and work together. Students can be divided into several groups. The members of the groups will introduce their personal experience in English, supplement and broaden their thinking through discussion. The writing task can also be regarded as the group work. Each member plays his own roles and does his oral presentation. The teacher-student interaction means that the teacher helps students solve their problems in the course of oral communication or written expression. The students, along with the teacher, work together to solve the problems. In the course of interactive experience, students learn their knowledge and broaden their ideas. On the basis of paragraph writing, English writing has conversed from sentence writing to paragraph writing.

\subsubsection{Abstract Conceptualization}

The third stage is the transformation of students from perception, interaction to understanding. They need to take discourse elements into account. Through the activities of abstract summary, they build a complete framework of English writing, including thinking about the theme, cohesion and coherence and logical expression. It is the key point in the process of their transformation of knowledge. At this stage, students can experience in a high level. After the completion of sentence writing and paragraph writing, they come to the discourse writing.

\subsubsection{Formal Passage}

In the first three stages, students complete a writing process from sentence to paragraph and discourse. The final stage is the formation of the passage and deepens the theme. From the viewpoints of themes, paragraphs and sentences, students can work together and modify the passage. The formation of the passage does not mean the end of writing. Experiential English writing is a process of rising cycle. As long as you are not satisfied, you can return to concrete experience and begin another new round of writing.

According to the concepts of experiential English writing and the concept of the student-orientation, we design a model of the four stages of the writing process.
The model is centered on the care of the students, and the four lines of the diamond represent the four stages of experiential English writing, namely, the concrete experience, the interactive experience, the abstract summary and the formation of the article. The four sides of the diamond stand for the detailed tasks in each stage, from the recording of the words and sentences, paragraph writing, text writing to the amendment. Note that the four sides of the diamond are the arrows instead of the lines. The three arrows among the concrete experience, the interactive experience, the abstract summary and the formation of the article indicate a set of procedures of experiential English writing and the order cannot be reversed. The last arrow points to the concrete experience, indicating that experiential English writing is a cycle of rise and can be turned back to begin a new circle. The inner parts of the diamond refer to the different psychological activities and the methods of knowledge construction, namely the perception experience, interactive communication, understanding and cooperation.

Compared with the traditional writing methods, experiential English writing requires that students should complete the writing process - from words and sentences, paragraph writing, text writing to themes, which is a great challenge to the traditional writing approach. Because the order of the product writing approach begins with setting the themes, layout, paragraph expansion and choices of the words and sentences, the result is that the articles are lack of the concrete experience though they seem to be great. The reason, on one hand, is that the students are short of life experience; on the other hand, the product writing only pays attention to the results of the final compositions instead of the writing processes. Students are lack of cooperative interaction. The compositions are only the results of thinking at home. In the light of the actual difficulties of students, experiential English writing pays attention to experience and interaction and lets students have things to write about. The author selected 1 class in 2012 Grade and compared it with another control class in order to check the necessity of experiential English writing and its advantages over the traditional product writing method.

\section{Experimental Analysis of Experiential English Writing}

\subsection{Research Objects}

The objects of the research are two classes of Grade 2012 in Anhui Sanlian College. Their English courses are taught by the same teacher, four periods each week and the same teaching process. Their English levels, age, gender, physical condition and educational background are quite similar. Forty-eight students of Class One will adopt the experiential English writing method; Fifty students of Class Two use the traditional product writing method. Before the experiment, we had a writing test, both got the average score of $8.1-8.4$ without any significant difference, so their writing level is roughly equivalent. 


\subsection{Research Questions and Methods}

The study mainly answers three questions: 1) Compared with the product writing method, can experiential English writing stimulate students' interests in English writing? 2) Can experiential English writing improve students' communicative ability? 3) Can experiential English writing improve their writing level?

The experiment adopted the methods of questionnaires and comparison, including their writing interests, their communication, as well as the different writing levels between Class One and Class Two.

\subsection{Data Analysis}

\subsubsection{Experiential English Writing can Stimulate Students' Interests in English Writing}

Before and after the experiment, we carried out a questionnaire survey on students' interests in English writing and collected the following data. The results are shown in Table 1.

Table 1. Results of interests in English writing before and after the experiment.

\begin{tabular}{|c|c|c|c|c|c|c|}
\hline \multirow[t]{2}{*}{ objects } & \multicolumn{3}{|c|}{$\begin{array}{l}\text { The number of interested } \\
\text { students before the } \\
\text { experiment }\end{array}$} & \multicolumn{3}{|c|}{$\begin{array}{l}\text { The number of interested } \\
\text { students after the } \\
\text { experiment }\end{array}$} \\
\hline & $\mathbf{A}$ & B & $\mathrm{C}$ & A & B & C \\
\hline Class & 7 & 26 & 15 & 29 & 14 & 5 \\
\hline percentage & $14.58 \%$ & $54.16 \%$ & $31.26 \%$ & $60.41 \%$ & $29.17 \%$ & $10.42 \%$ \\
\hline Class Two & 9 & 25 & 16 & 17 & 19 & 14 \\
\hline percen & $18 \%$ & $50 \%$ & $32 \%$ & $34 \%$ & $38 \%$ & $28 \%$ \\
\hline Note & \multicolumn{6}{|c|}{ A: Interested B: A little interested C: Uninterested } \\
\hline
\end{tabular}

Data show: before the experiment, the writing interests of students of two classes with little differences; after the experiment, the writing interests of students of two classes with obvious difference. The other variables are under the control, and the different ways of experiential English writing and the product writing are the reasons for the differences in interest. Students who are interested in English writing in Class One before the experiment are 7, accounting for $14.58 \%$; after the experiment the figure is 29 (accounting for60.41\%). The great changes show that experimental English writing method is a great success and stimulates the writing interests of students. Students who are interested in English writing in Class Two before the experiment are 9, accounting for $18 \%$; after the experiment the figure is 17 (accounting for $34 \%$ ). The number of students interested in English writing has only increased a little.

\subsubsection{Experiential English Writing can Improve Students' Communicative Ability}

In a week after the experiment, the author counted the different forms of discussion in the writing process. The result is as Table 2:

Table 2. The times of communication in the writing process.

\begin{tabular}{llllll}
\hline $\begin{array}{c}\text { items } \\
\text { objects }\end{array}$ & $\begin{array}{l}\text { Student } \\
\text { - student }\end{array}$ & $\begin{array}{l}\text { Student } \\
\text { - group }\end{array}$ & $\begin{array}{l}\text { Group - } \\
\text { group }\end{array}$ & $\begin{array}{l}\text { Teacher - } \\
\text { student }\end{array}$ & $\begin{array}{l}\text { total } \\
\text { times }\end{array}$ \\
\hline Class One & 104 & 46 & 21 & 32 & 203 \\
Class Two & 21 & 15 & 12 & 33 & 81 \\
\hline
\end{tabular}

Data show that the total number of communication in writing process in Class One is 203 times, and 81 times in Class Two. The times of communication in Class One are more than those in Class Two. The students in Class One focus on the form of student-student communication. The students in Class One were encouraged to talk and write in the process of discussion. However, the students in Class Two are mainly one-way communication between teachers and students, lacking of communication among classmates. Most of them finished their writing by themselves.

\subsubsection{Experimental English Writing can Help Students Make Sentences Accurately and Improve Their Writing Level}

Table 3. The results of writing level before and after the experiment.

\begin{tabular}{|c|c|c|c|c|c|c|c|c|c|c|c|c|c|c|c|c|}
\hline \multirow[t]{2}{*}{ objects } & \multirow[t]{2}{*}{ items } & \multicolumn{3}{|c|}{ Theme } & \multicolumn{3}{|c|}{ Logic } & \multicolumn{3}{|c|}{ Vocabulary } & \multicolumn{3}{|c|}{ Sentence } & \multicolumn{3}{|c|}{ Contents } \\
\hline & & $\mathrm{A}$ & $\mathrm{B}$ & $\mathrm{C}$ & A & $\mathrm{B}$ & $\mathrm{C}$ & $\mathrm{A}$ & $\mathrm{B}$ & $\mathrm{C}$ & $\mathrm{A}$ & $\mathrm{B}$ & $\mathrm{C}$ & $\mathrm{A}$ & $\mathrm{B}$ & $\mathrm{C}$ \\
\hline Before the & Class One & 17 & 20 & 11 & 16 & 17 & 15 & 11 & 22 & 15 & 10 & 21 & 17 & 9 & 20 & 19 \\
\hline experiment & Class Two & 19 & 23 & 8 & 18 & 19 & 13 & 14 & 20 & 16 & 14 & 21 & 15 & 11 & 22 & 17 \\
\hline After the & Class One & 19 & 21 & 8 & 19 & 16 & 13 & 24 & 16 & 8 & 21 & 17 & 10 & 25 & 16 & 7 \\
\hline experiment & Class Two & 23 & 20 & 7 & 20 & 21 & 9 & 16 & 22 & 12 & 16 & 20 & 14 & 15 & 20 & 15 \\
\hline Note & \multicolumn{16}{|c|}{ A: Good B: Medium C: Poor } \\
\hline
\end{tabular}

Before the experiment, students in both classes are almost in same level in the aspects of theme, logic, vocabulary, sentence and content. After the experiment, their compositions are also in the same level in the aspects of theme and logic, but great differences in the aspects of vocabulary, sentence and content. The obvious differences indicate that the methods of experience, interaction and discussion in experimental English writing are very effective, which help students have wise diction, broaden their writing ideas and enrich the writing contents so as to improve their writing ability.

\subsection{Qualitative Analysis}

After the experiment, we held a meeting about experimental English writing and the great changes. A student said, "I did not often write the composition and could not find suitable writing materials. But now everything changes. Through the ways of concrete experience and interaction, I can broaden my views and no longer worry about writing." Another student said, "I used to hate writing, because I often did it alone. No one can discuss with. It is conceivable that the materials are put at 
random, who loves it? With experiential English writing, everyone can brainstorm and solve the problems together in the writing process, which arouses my interest in English writing. Besides this, I can improve my oral English level." The essence of the writing course is to meet the needs of expression, to respect the understanding of life, and to reflect the humanistic values. Experiential English writing advocates writing in experience and interactive communication. The writing time is free and the writing space is open. In this way, there are some advantages in experiential English writing. The qualitative analysis further confirms the above-mentioned results.

\section{Conclusion}

The quantitative and qualitative analyses show that experiential English writing method helps students stimulate their writing interests, improve their communicative ability, choose the suitable words and sentences, increase the writing contents and improve their writing level. These show that experiential English writing is superior to the traditional product writing method and has the feasibility and necessity to promote it. It is a good attempt and effective innovation for the reform of College English teaching.

\section{Acknowledgements}

The paper is one of the results of Educational Quality Project of Anhui Provincial Education Department; Code: $2013 z y 086$.

\section{References}

[1] Du Aihong. A Study on the Application of Meta-cognition in College English Writing [J]. China Adult Education, 2008,(6).
[2] Kolb David A. Experiential Learning: Experience as the Source of Learning and Development [M]. London: Pearson Education Inc, 1984.

[3] Niu Xiao. On the Effects of Economic Principles on College English Writing Teaching [J]. Theory and Practice of Education, 2014, (6).

[4] Shao Jirong. Effects of Task Type and Task Condition on EFL Writing [J]. Foreign Language Teaching, 2003, (2).

[5] Wang Chuming, An Experiment on English Writing [J]. Foreign Language Teaching and Research, 2000, (3).

[6] Wu Hongyun. An Empirical Study on the Meta-cognition Theory as a Second Language [M]. Beijing: Foreign Language Teaching and Research Press, 2006.

[7] Wu Jin, Zhang Zaixin. A New Study on English Writing Teaching $[\mathrm{J}]$. Foreign Language Teaching and Research, $2000,(3)$.

[8] Wang Wenyu, Wang Lifei. The Research on Writing as a Second Language [J]. Foreign Language World, 2004, (3).

[9] Yang J, Yu X. The Impacts of Reading on Language Development in L2 Writing [R]. Beijing: Beijing Foreign Studies University, 2011.

[10] Yang Yonglin, Luo Lisheng. Experiential English Writing: A System Based on Digital Teaching Theory [J]. Computer-Assisted Foreign Language Education, 2004, (4).

[11] Yi Jingshu. College English Writing Teaching and Empathy Experience [J]. Zhejiang Ocean University, 2005, (3).

[12] Zhang Lian. The Construction of Interactive Mechanism Between the Reform of English Major Curriculum and Teachers' Development ---- Students of BFSU College As an Example [J]. Foreign Languages and Their Teaching, 2013, (3).

[13] Zheng Yaofei, Chen Songqin. A Study of College English Writing Chains Based on Genre Theories [J]. Higher Education Exploration, 2014, (1). 